\title{
DESIGNING A MODEL FOR MAKING DECISION ABOUT OUTSOURCING ACTIVITIES IN BANKING SYSTEM
}

\author{
Ahmad Hosseini Golafshan ${ }^{1}$ \\ Mahmood Modiri ${ }^{2}$ \\ Parvaneh Gelard
}

\begin{abstract}
Despite the growing trend of outsourcing of financial services in recent decades, most outsourcing projects have failed due to the qualitative nature of decision-making criteria and lack of paying attention to differences in environmental conditions. The aim of this research is to design a model for decision making about outsourcing activities in the public banks. This research is applied and developmental study in terms of objective and descriptive-survey in terms of data collection method. The research tool was interview in qualitative section and a questionnaire in quantitative section.
\end{abstract} banking experts in 6 public banks and central bank. After studying the theoretical foundations and exploratory interviews, the initial model was The research population included

identified. Then, the final model of the research was identified with 6 factors and 22 sub-factors using the fuzzy Delphi method. Fuzzy DEMATEL and fuzzy ANP methods were used to examine the relationship between criteria and weighting the factors. Finally, "logistics and support sector activities" option with the highest weight was rank first and selected for outsourcing using gray and fuzzy MOORA methods. Moreover, the activity of the "human resources" sector was ranked second and the "legal and claims receivable sector activities" option was ranked last.

Keywords: Decision-making, outsourcing activity, public banks

\section{1-Introduction}

\footnotetext{
${ }^{1}$ PH.D in public adminstration,Assistant Professor, Department of public adminstration, Islamic Azad University,south Tehran Branch. Email: a_hosseini@azad.ac.ir

${ }^{2}$ PH.D in industrial management,Assistant Professor, Department of industrial management, Islamic Azad University, Tehran South Branch. Email: m_modiri@azad.ac.ir.
} 
Considering the great advances in the business environment, including globalization, information technology advances, public sector reforms, increased competitive pressure, highspeed technological change and the diffusion of knowledge across different companies and markets with geographically different positions in the last two decades have forced organizations to respond increasingly to customers' needs. For this purpose, many organizations that were hierarchically controlled in the past have been forced to outsource their activities to specialist suppliers (Mcivor, 2008).

In this regard, managers in Iran have faced continued emergence of management tools. In the last two decades, tools such as ISO 9000, productivity improvement systems, organizational excellence models, administrative transformation programs, service compensation systems, process reengineering, outsourcing, strategic planning, etc. have been introduced into work plans of organizations (Akbari and Nikzad, 2011). Nowadays, organizations consider outsourcing as an operational necessity and plan many services for outsourcing. Due to the involvement of different decision making groups as well as the interrelationships between outsourcing criteria and options, outsourcing decision making on processes and selecting outsourcing contractor is a process that requires examining different and sometimes conflicting theories of experts considering the multiple and complex quantitative and qualitative factors. Inaccurate and wrong decision-making is associated with payment of cost for errors and it is irreversible in some cases and requires the use of robust and practical techniques in the area (Masrur et al., 2018). Since the 1980s, an outsourcing trend has begun in organizations. It starts with outsourcing of information systems and continues up to the advanced strategic and transformational outsourcing level. It involves outsourcing the core and strategic business activities (Schniederjans et al. 2007).

Numerous previous studies have investigated the phenomenon of outsourcing and its various aspects, different types of outsourcing in terms of the nature and scope of activity, and sourcing models in terms of service delivery and seller location. Large 
volume of the previous studies have focused on outsourcing IT-related activities (Ai et al., 2019) such as digital logistics (Teo et al., 2014), e-commerce (Grandon and Pearson, 2004), e-business (Zhu and Kraemer, 2005), and organizational resource planning (Amoako-Gyampah and Salam, 2004).

Some previous studies have also considered the benefits and risks associated with outsourcing (Di Gregorio et al., 2009) and have focused on success and failure of outsourcing projects (Law , 2018). In addition, past studies have also investigated the factors affecting outsourcing of logistics (Zhu et al, 2017). However, limited number of studies has investigated the decisionmaking process for outsourcing activities in the banks as a whole. Hence, this study was conducted with the aim of designing and developing a model to help managers in decision making with regard to outsourcing of activities. In addition, outsourcing of financial services has grown in recent decades. Banks, along with other organizations around the world, are increasingly outsourcing their activities. Regardless of non-core activities such as maintenance services, security services, property and buildings maintenance, preparing food, etc., which their outsourcing have become obligatory in some cases, many banks are significantly outsourcing IT processes, administrative affairs, and human resources (Tabatabaei and Mohammadi, 2015). It has been globally observed that the banking industry has a high potential to make a profit from outsourcing given the nature of information technology (Tas and Sunder, 2004). In fact, industry studies have shown that the banking and financial services industry, after production, has been the largest user of outsourcing services sector around the world (Ackermann, 2003). Despite increasing knowledge of managers of this issue, most outsourcing projects in financial institutions are facing problems such as increased costs (Frost and Sullivan, 2004), reduced employee motivation (Liapopoulos and Moschuris, 2013) due to the qualitative nature of decision-making criteria and lack of attention to differences in environmental conditions and various risks. Some previous studies conducted on outsourcing in the banking industry have investigated some of the advantages and disadvantages of outsourcing in the 
banking industry (Tayauova, 2012). Moreover, a large number of studies have investigated outsourcing of IT in banking industry foreign countries (Blumenberg et al., 2009) as well as information systems in this industry (Adeleye et al., 2004). Another study conducted by Hanifzadeh et al in Iran in 2017 investigated the factors affecting the decision-making on e-banking outsourcing.

This study investigates the decision-making criteria for outsourcing of activities in Iran's public banks. According to the general policies of Article 44 of the Constitution, the stocks of Iranian Banks, including Melli, Sepah, Sanat and Madan, Keshavarzi, Maskan and Tosee cannot be transferred to the private sector. Given the important role of these banks in the Iran's economy and the intense competition of the banking network, outsourcing the activities of these banks from a scientific point of view can greatly help these banks to improve their efficiency and effectiveness.

Hence, this research was conducted to improve the decisions made on outsourcing of banking industry activities in Iran's public banks. In general, the present study seeks to answer the question of what are the principles and criteria for making decision on outsourcing of activities in banks, given the specific sensitivity and duties of banks and financial Institutes, and how are the effects between criteria, weighting, and priority of activities for outsourcing.

The research literature was reviewed first to become familiar with the concept of outsourcing and in particular the factors affecting the decision-making of outsourcing activities. Next, the research methodology will be discussed. Then, the research model and results will be presented, and finally, the conclusion of the research will be presented.

\section{2- Literature Review}

2.1-Definition of outsourcing The term "outsourcing" was first used in 1989 to describe Kodak Company's decision in outsourcing its information technology activities to one of the IBM subsidiary companies as a business strategy (Tjader et al., 2014). However, before it, many companies were not doing all of their activities themselves and were outsourcing their 
activities with lower competition potential to external contractors. Outsourcing has been a type of "manufacturing-purchasing" decision (Gray, 2006). Outsourcing in current organizations is rapidly finding its main position and it will be used rapidly. Theoretical foundations of outsourcing suggest that no single and unique definition has been provided on outsourcing. Experts have provided different definitions for outsourcing. Tayauova (2012) defines outsourcing as the process of assigning operations or jobs to a third party who can do it better. Choudhry (2014) views outsourcing as providing products and services from sources outside the organization.

Perunović (2007) categorized all planned processes into five stages, including initial evaluation and outsourcing decision making, contractor selection, transfer, relationship management, and reconsideration. In this stage, the first stage, initial evaluation and outsourcing decision making, is considered.

Sia et al. stated that "outsourcing is a strategic option that few organizations can ignore it" (Sia et al., 2008). Ignoring outsourcing makes it impossible to use of its benefits and advantages. Various and sometimes incomplete and exaggerated reasons have been reported for benefits of outsourcing. (2012) In a study on 1,200 companies, Outsourcing Institute concluded that the main reasons for outsourcing were controlling and reducing operating costs, improving organization concentration, benefit of access to world-class capabilities, releasing internal resources for other goals, access to resources that are not available within the organization (access to external resources), accelerating the benefits of reengineering, managing difficult or uncontrolled performance, accessing funds, risk sharing and cash injection. Outsourcing also improves flexibility to change work conditions, demand for products, services, and technologies (Lee and Lan, 2013).

The decision-making criteria for outsourcing internal and external activities and factors affecting these decisions can be divided into the following dimensions.

2-2-Criteria for making deciding on outsourcing of activities in banks 
2.2.1-Criteria related to enhancing organizational capability

Strategic outsourcing is a tool for risk-sharing and transfer of investment and business risks by forming an investment portfolio for different areas of its business and selecting different contractors and the way of outsourcing organizational activities, which cut the costs, use capital and force of other companies and reduces the risk of lack of technology, technical knowledge, and skill (Parvyzyan, 2006).

\subsection{2- Security criteria}

Information security is one of the most influential criteria in outsourcing banking activities (Click and Duening, 2004). In the outsourcing process, organizations must provide useful confidential and specialized information to contractors. Therefore, an organization should consider intellectual property rights when selecting an external sourcing structure option (Sean, 2009). In general, it is essential for organizations to ensure that service providers meet security-related indicators and criteria (Hanifizadeh, 2017).

2.2.3- Technological criteria
The use of new technology tools and development of business enterprises are vital for gaining advantage and growth of organizational capability in global competition. Hence, much attention should be paid on making decision to deploy new technology due to its sensitivity, high cost and risk of success. Moreover, before taking any action, necessary information needs to be collected and analyzed (Farzad et al., 2012). It is necessary to update the information in providing some services including banking services. The more important this factor is in production of a product or service in an organization, the more its activities will be influenced by technology (Tayles, 2001).

\section{2-2-4-Management criteria}

Outsourcing management goals include managers' access to more time, reducing managers' trivial tasks, and facilitating the management of difficult tasks. The biggest concern of employees is job security that is compromised by outsourcing. Therefore, in evaluating outsourcing decision, it is necessary to consider its effects on morale, motivation and loyalty of the employees (Olfat and Barati, 2010). Reduced 
motivation due to lack of job security decreases the interest in controlling the environment and employees will less perform their duties (Axelrod, 2009). Quality improvement, including quality planning, quality control, and quality assurance can also be considered as management goals. (Assaf, 2011). In a study entitled "Outsourcing of accounting tasks and its impact on the quality of financial reporting", Hoglund (2016) showed that outsourcing of accounting tasks such as providing legal financial statements as well as having long-term relationships with service providers enhances the quality of reporting. However, outsourcing of other tasks such as payment of wage does not lead to higher quality in this area. In a study entitled "factors affecting outsourcing of the logistics sector (documents from Malaysian companies)", Zailani (2015) also found a positive relationship between outsourcing and performance.

2.2.5-Criteria related to service and goods suppliers

In order to outsource an activity, a company requires potential suppliers for that activity. If there is only one supplier, the company needs to show lower tendency to outsource the activity, because it is associated with a risk of complete dependence on the supplier. In addition, lack of paying attention to the contractor's background and experience along with the tools, capabilities and technical knowledge of supplier in the outsourced process can lead to failure in outsourcing process. Moreover, the contractor must have a reasonable financial capacity in order to prevent the interruption in the outsourced process when facing with financial problems (Masrour et al, 2018). In a study entitled "effective factors of outsourcing in US municipalities", Zhang and Gibson (2016) showed that although external stakeholders' involvement is an influential factor in outsourcing, lack of appropriate service suppliers is one of the important barriers of outsourcing in organizations.

\subsection{6- Criteria related to} characteristic of the activity outsourced The question that arises in outsourcing is to what extent performing an activity in the organization is necessary and important and if lack of 
performing it actually disrupts the system or not (Kuhani et al, 2013).

In addition, as an activity becomes more tangible, it will be more difficult to monitor the performance (and quality) of the service delivered to the customer. For example, in air flights, it is very difficult to monitor the performance of the crew during flight because such services are performed practically and experimentally. For this reason, very few airlines assign their flight crew activities to the private sector. However, monitoring the quality of food served on the fly is very easy, because the food is inherently tangible. If it is difficult to evaluate and monitor a performance, the tendency to outsource will decrease (Alvani et al., 2012).

2.3- External influential factors 2.3.1-Social criteria influencing the outsourcing of activities

The expansion of civil community and the establishment of democracy in communities, along with other social developments in Western communities have led development of new perspectives that rely on the renewal of government intervention in citizen affairs, assigning the activities to non-
195

public sector, privatization, outsourcing, and so on (Lewis, 2001). Additionally, during outsourcing, many employees may be fired because of outsourcing contracts. Outsourcing reduces the demand for low skilled workers and can increase unemployment. Therefore, outsourcing:

-Reduces the wages and increases unemployment for low skilled workers

-Increases inequality between high and low income groups.

-Increases the cost of social insurance (Keuschnigg, 2009).

\subsection{2- Economic factors}

The technological process and globalization of the financial services has made banks face increased competitive pressure and focus on optimizing operations and productivity, performed often through merging and acquiring the ownership of companies and outsourcing (Fiorentioni, 2009). Due to government restrictions in financing the domestic economy (inefficiency of the tax system) in Iran, the control of the government over the banking system has increased. Unfortunately, despite the strong tendency to reduce the control of 
government, it has not been achieved so far and stock market and securities boom failed to increase the depth of the financial markets, so the firms' ability to attract capital has weakened (Isa Zadeh and Saheri, 2012).

2.3.3- Political and legal factors External pressure from business partners, competitive pressures, laws and policies of governments can influence decisions of the companies. For example, government policies may put pressures on companies to improve and use modern technology (Hanafizadeh, 2017). One of the major barriers to outsourcing is the conflict between unions and labor unions because, despite processes such as privatization and outsourcing, many employees of the organization will lose their jobs, and take actions such as protest (Rajabzadeh, et al., 2010). Privatization and the transfer of control of affairs to private sector have been on the agenda of Iran's authorities in past decades. According to the relevant laws (National Service Law, Article 44 of the Constitution, 20-year Vision 1404, five-year development plans laws, etc.), outsourcing of the processes and activities of organizations and changes in this regard have been emphasized by senior officials of Iran (Bagheri et al., 2015).

\section{4-Internal influential factors}

2.4.1-Mission and strategy of the organization

As the mission of the organization is proving guidance for doing the works and adopting different strategies, those activities that are consistent with the organization's vision must be maintained and rest of activities must be outsourced to external organizations (Dastyari et al., 2014). According to the subject literature and interviews with experts, making organization agile and decentralization are among the major objectives (missions) in the issue of bank outsourcing. Reforming organizational structure and processes, human resource development, and so on are among the strategies of the study banks in the strategic planning process. Although today's companies around the world are moving towards outsourcing to achieve benefits such as cut in cost, access to advanced technology, etc., differences in organizational cultures and complexity of management of relationships created 
in outsourcing can lead to failure or dissatisfaction (Rezaei et al., 2015).

\section{2-4-2-Cultural factors}

Proper work interaction among employees of a company reduces time and increases productivity. Companies whose relationships are based on personal communications among the employees not merely based formal contracts have stronger relationships. Strong communication between two organizations will result in increased problem solving, cooperation, mutual trust, mutual satisfaction and confidence in the relationships of the parties (Gottschalk, 2006).

\subsection{3- Size of organization}

The size of the organization increases the ability of the organization to pay training and maintenance related costs. Increasing the size of the organization increases the ability to access large amounts of the resources required and increases the ability to better manage the risks associated with outsourcing. Moreover, large companies have more experience with suppliers' management than smaller ones. As a result, they will be probably more successful in managing and signing
197

outsourcing contracts. (Hanifizadeh, 2017).

Based on the research literature and exploratory interviews, the factors of politics, missions, size and culture were identified as influential factors of internal environment and economic, political, legal and social factors were identified as influential factors of external environment.

3-research methodology

This study was conducted to identify the dimensions and components of decision-making regarding outsourcing of Iran's public banks. In order to answer the main question, the following questions were asked in the research :

-What are the elements of decision-making model of outsourcing of activities in the banking system?

-How is the interaction of elements of the decision-making model of activities outsourcing in the banking system?

-What is the priority of each of these factors?

-What are the effective factors (internal and external) in the outsourcing decision-making model? 
-What is the appropriate model for outsourcing activities in the banking system?

-Which of the banking system activities are in priority of outsourcing?

he research is an applied and developmental study in terms of objective and descriptive-survey in terms of method of collecting data and information. In this study, questionnaire on a Likert scale in fuzzy Delphi method as well as DEMATEL and Vikor questionnaire were used to investigate the effects of criteria, weighting, etc. for fuzzy calculations. The geographical domain of the research is limited to Tehran and it was carried out between autumn 2017 and winter 2018.

The opinions and views of experts, university professors and related experts in the banking system were used in this study. Since the study included six public banks, the relevant heads of departments (organization and human resources, etc.) who had more than 15 years of employment history in public banks, including experts in the areas of organization, management of studies and baking regulations and human resources of the Central Bank were selected to join the Delphi Group. Snowball technique was used to select the experts. In this technique, some managers with characteristics such as having relevant postgraduate studies, relevant scientific experience especially managerial experience, sufficient motivation for participation and cooperation were selected. Then, 20 individuals (14 from public banks and 6 central banks) were identified with similar characteristics. Moreover, in the data analysis stage, 7 banking experts' views of were used.

The main stages of this research are:

1- Initial identification of the elements of the decision-making framework for outsourcing activities in Iran's public banks after reviewing the outsourcing literature and various decision-making models and exploratory interviews.

2- Developing and testing the initial model by selecting the fuzzy Delphi method and using the views of banking system experts and designing the final model

3-Collecting information using questionnaires and finally using fuzzy DEMATEL and fuzzy ANP methods for inter-criteria effects, weighting and prioritizing of decision making criteria 
and fuzzy MOORA and gray MOORA for ranking and prioritizing activities

4- Designing and identifying the elements of the decision making model

In the theoretical stage, the conceptual model and theoretical framework were developed based on the theoretical foundations and different models. At this stage, the dimensions, components, and indicators extracted from theoretical foundations and studies conducted on the subject and exploratory studies were used as a base for identification of the conceptual model. Then, during several stages of exploratory interview with banking system experts and after numerous reviews and consultation with 15 honorable professors of university, dimensions and components were identified and initial model was designed.

4-1-Model identification using Fuzzy Delphi method

The fuzzy Delphi method was invented in the 1980s by Kaufman and Gupta (Cheng and Lin, 2002). Using this technique to make decision and reaching a consensus on issues whose goals and parameters are not explicitly stated yields very valuable results. At this stage, the conceptual model and a questionnaire with 29 questions (each question representing one factor) were sent to 20 expert group members and their agreement on each of the factors were obtained and their suggested and corrective views were applied. These questionnaires are scored qualitatively on a five-point Likert scale ranging from extremely important to unimportant. At this stage, the conceptual model presented along with a questionnaire with 29 questions (each question representing one factor) was sent to 20 expert group members and their agreement with each of the factors obtained and their suggested and corrected points of view. Split. These questionnaires were qualitatively based on five Likert ranges from extremely important to unimportant.

Then, the second questionnaire was prepared and sent back to the expert group along with the previous views of each individual and their differences with the views of other experts were sent to expert groups. In the second stage, the expert team members again responded to the questions based on the views of the other group members. According to the 
views presented in the first stage and comparing with the results of this stage, if the difference between the two stages is less than the threshold of 0.2 , the survey process stops. As expert groups reached a consensus in some of the components and the rate of disagreement in the first and second stages was less than the threshold of 0.2 , the survey on these factors stopped and the factors in which the defuzzified mean of the experts' view was less than 8 were excluded from the conceptual model of the research. At this stage, 24 factors stopped and survey was performed on rest of 5 factors in the third stage.

Finally, during the three-stage survey of 29 factors, 7 factors were excluded from the final conceptual model of the research and the final model consisted of 22 factors.

Table 1-1: Factors and secondary factors affecting the decision-making on outsourcing of activities

\begin{tabular}{|c|c|c|}
\hline Main factors & Secondary factors & Abbreviations \\
\hline \multirow{3}{*}{$\begin{array}{l}\text { Security } \\
\text { C1 }\end{array}$} & Lack of access to confidential organization & $\mathrm{C} 11$ \\
\hline & $\begin{array}{l}\text { Defect in dependency on companies providing } \\
\text { service }\end{array}$ & $\mathrm{C} 12$ \\
\hline & Defect in disclosing information of clients & $\mathrm{C} 13$ \\
\hline \multirow{4}{*}{$\begin{array}{l}\text { Organization's } \\
\text { capability } \\
\text { C2 }\end{array}$} & Improving the capability and releasing the human & $\mathrm{C} 21$ \\
\hline & Eliminating non-core activities & $\mathrm{C} 22$ \\
\hline & Obtaining competitive advantage & $\mathrm{C} 23$ \\
\hline & Access to specialty of contractors & $\mathrm{C} 24$ \\
\hline \multirow{4}{*}{$\begin{array}{l}\text { Technological } \\
\text { C3 }\end{array}$} & Lack of human resource in applying technology & $\mathrm{C} 31$ \\
\hline & Complexity of technology & $\mathrm{C} 32$ \\
\hline & Access to new technology & $\mathrm{C} 33$ \\
\hline & Technological uncertainty (rapid changes in & $\mathrm{C} 34$ \\
\hline \multirow{5}{*}{$\begin{array}{l}\text { Management } \\
\text { C4 }\end{array}$} & Improving controlling and monitoring & $\mathrm{C} 41$ \\
\hline & Improving service quality & $\mathrm{C} 42$ \\
\hline & Motivation and morale of employees & $\mathrm{C} 43$ \\
\hline & Cost & $\mathrm{C} 44$ \\
\hline & Speed of provision of services by contractors & C51 \\
\hline
\end{tabular}




\begin{tabular}{|l|l|l|}
\hline \multirow{2}{*}{$\begin{array}{l}\text { Suppliers' } \\
\text { market }\end{array}$} & Multiple and potential contractors & C52 \\
\cline { 2 - 3 } & Experience and background of contractors & C53 \\
\hline \multirow{2}{*}{$\begin{array}{l}\text { Activity } \\
\text { characteristic } \\
\text { C6 }\end{array}$} & Standardization of activities & C61 \\
\cline { 2 - 3 } & Simplicity or complexity of activity & C62 \\
\cline { 2 - 3 } & Tangibility of activity & C63 \\
\cline { 2 - 3 } & The level of dependency of an activity to other & C64 \\
\hline
\end{tabular}

\section{5- Results}

The step of examining the internal relationships between the factors using the F.DEMATEL method is as follows:

To prepare the fuzzy direct relationship matrix, the experts answered the level of effect of each of the factors influencing each other based on the scale ranging from very high effect (4), high effect (3), medium effect (2), low effect (1) and no effect (0). Then, the answers were converted to fuzzy numbers and arithmetic mean of opinions was obtained. Table (1) shows the fuzzy direct relationship matrix for the primary and secondary factors.

Matrix of fuzzy direct relationships between factors

\begin{tabular}{|l|lll|lll|lll|lllll|llllll|lllll|}
\hline & $\mathrm{C} 1$ & & & $\mathrm{C} 2$ & & & $\mathrm{C} 3$ & & & $\mathrm{C} 4$ & & & $\mathrm{C} 5$ & & & C6 & & \\
\hline & $\mathrm{L}$ & $\mathrm{M}$ & $\mathrm{U}$ & $\mathrm{L}$ & $\mathrm{M}$ & $\mathrm{U}$ & $\mathrm{L}$ & $\mathrm{M}$ & $\mathrm{U}$ & $\mathrm{L}$ & $\mathrm{M}$ & $\mathrm{U}$ & $\mathrm{L}$ & $\mathrm{M}$ & $\mathrm{U}$ & $\mathrm{L}$ & $\mathrm{M}$ & $\mathrm{U}$ \\
\hline $\mathrm{C}$ & 0 & 0 & 0 & 0. & 0. & 0. & 0. & 0 & 0. & 0. & 0. & 0. & 0. & 0. & 0. & 0. & 0. & 0. \\
$\mathrm{C}$ & 0. & 0. & 0. & 0 & 0 & 0 & 0. & 0 & 0. & 0. & 0. & 0. & 0. & 0. & 0. & 0. & 0. & 0. \\
$\mathrm{C}$ & 0. & 0. & 0. & 0. & 0. & 0. & 0 & 0 & 0 & 0. & 0. & 0. & 0. & 0. & 0. & 0. & 0. & 0. \\
$\mathrm{C}$ & 0. & 0. & 0. & 0. & 0. & 0. & 0. & 0 & 0. & 0 & 0 & 0 & 0. & 0. & 0. & 0. & 0. & 0. \\
$\mathrm{C}$ & 0. & 0. & 0. & 0. & 0. & 0. & 0. & 0 & 0. & 0. & 0. & 0. & 0 & 0 & 0 & 0. & 0. & 0. \\
$\mathrm{C}$ & 0. & 0. & 0. & 0. & 0. & 0. & 0. & 0 & 0. & 0. & 0. & 0. & 0. & 0. & 0. & 0 & 0 & 0 \\
\hline
\end{tabular}

Matrix of fuzzy direct relationships between secondary factors

\begin{tabular}{|l|lll|lll|l|lll|lll|}
\hline & $\mathrm{C} 11$ & & & $\mathrm{C} 12$ & & $\mathrm{C}$. & $\mathrm{C} 63$ & & & C64 & \\
\hline & $\mathrm{L}$ & $\mathrm{M}$ & $\mathrm{U}$ & $\mathrm{L}$ & $\mathrm{M}$ & $\mathrm{U}$ & & $\mathrm{L}$ & $\mathrm{M}$ & $\mathrm{U}$ & $\mathrm{L}$ & $\mathrm{M}$ & $\mathrm{U}$ \\
\hline C1 & 0 & 0 & 0 & 0.1 & 0.2 & 0.5 & $\ldots$ & 0.1 & 0.2 & 0.5 & 0.1 & 0.2 & 0.5 \\
C1 & 0.0 & 0.2 & 0.4 & 0 & 0 & 0 & $\ldots$ & 0.2 & 0.4 & 0.6 & 0.1 & 0.2 & 0.5 \\
C1 & 0.4 & 0.6 & 0.8 & 0.0 & 0.2 & 0.5 & $\ldots$ & 0.1 & 0.2 & 0.5 & 0.0 & 0.2 & 0.4 \\
C2 & 0.1 & 0.2 & 0.5 & 0.2 & 0.5 & 0.7 & & 0.1 & 0.2 & 0.5 & 0.1 & 0.2 & 0.5 \\
C2 & 0.0 & 0.2 & 0.4 & 0.0 & 0.2 & 0.4 & $\ldots$ & 0.1 & 0.3 & 0.6 & 0.3 & 0.5 & 0.7
\end{tabular}




\begin{tabular}{|l|lll|lll|l|lll|lll|} 
C2 & 0.3 & 0.5 & 0.7 & 0.3 & 0.5 & 0.7 & $\ldots$ & 0.1 & 0.2 & 0.5 & 0.1 & 0.2 & 0.5 \\
C2 & 0.0 & 0.2 & 0.5 & 0.2 & 0.5 & 0.7 & $\ldots$ & 0.0 & 0.2 & 0.4 & 0.0 & 0.1 & 0.4 \\
C3 & 0.0 & 0.2 & 0.5 & 0.4 & 0.6 & 0.7 & & 0.1 & 0.3 & 0.5 & 0.1 & 0.3 & 0.5 \\
C3 & 0.0 & 0.2 & 0.4 & 0.4 & 0.6 & 0.8 & & 0.1 & 0.2 & 0.5 & 0.0 & 0.2 & 0.4 \\
C3 & 0.1 & 0.2 & 0.5 & 0.3 & 0.5 & 0.7 & $\ldots$ & 0.1 & 0.2 & 0.5 & 0.1 & 0.3 & 0.5 \\
C3 & 0.0 & 0.1 & 0.4 & 0.2 & 0.5 & 0.7 & $\ldots$ & 0.1 & 0.2 & 0.5 & 0.0 & 0.1 & 0.4 \\
C4 & 0.5 & 0.7 & 0.8 & 0.4 & 0.6 & 0.7 & $\ldots$ & 0.4 & 0.5 & 0.7 & 0.3 & 0.5 & 0.7 \\
C4 & 0.0 & 0.2 & 0.4 & 0.2 & 0.5 & 0.7 & & 0.1 & 0.2 & 0.5 & 0.0 & 0.2 & 0.4 \\
C4 & 0.1 & 0.2 & 0.5 & 0.2 & 0.4 & 0.6 & & 0.2 & 0.4 & 0.6 & 0.2 & 0.4 & 0.6 \\
C4 & 0.3 & 0.5 & 0.7 & 0.3 & 0.5 & 0.7 & $\ldots$ & 0.1 & 0.3 & 0.5 & 0.1 & 0.3 & 0.5 \\
C5 & 0.0 & 0.1 & 0.4 & 0.2 & 0.4 & 0.6 & $\ldots$ & 0.0 & 0.2 & 0.4 & 0.0 & 0.2 & 0.4 \\
C5 & 0.2 & 0.4 & 0.6 & 0.5 & 0.7 & 0.8 & $\ldots$ & 0.0 & 0.1 & 0.4 & 0.1 & 0.2 & 0.5 \\
C5 & 0.3 & 0.5 & 0.7 & 0.1 & 0.3 & 0.6 & & 0.0 & 0.2 & 0.4 & 0.0 & 0.1 & 0.4 \\
C6 & 0.0 & 0.1 & 0.4 & 0.1 & 0.3 & 0.5 & & 0.0 & 0.2 & 0.5 & 0.1 & 0.2 & 0.5 \\
C6 & 0.1 & 0.3 & 0.5 & 0.2 & 0.5 & 0.7 & & 0.1 & 0.2 & 0.5 & 0.2 & 0.4 & 0.6 \\
C6 & 0.1 & 0.3 & 0.5 & 0.1 & 0.3 & 0.5 & & 0 & 0 & 0 & 0.0 & 0.2 & 0.4 \\
C6 & 0.0 & 0.1 & 0.4 & 0.3 & 0.5 & 0.7 & & 0.1 & 0.3 & 0.5 & 0 & 0 & 0 \\
\hline
\end{tabular}

Note: Due to the small size of page and the large size of the matrix ( $24 \times 24)$, the matrix has been summarized.

Then, using other steps of fuzzy DEMATEL, the normalized fuzzy direct relationships matrix was formed. Finally, the sum of column elements and the row of matrix $\tilde{\mathrm{T}}$ was calculated for the primary factors and their secondary factors and presented as $\tilde{D}$ (influencing) and $\mathrm{R}^{\tilde{1}}$ (influenced) vectors. The calculations are presented in Table 1-2.

Table 2-1: The values of $\tilde{D^{\prime}}, \tilde{R}, \tilde{D}+\tilde{R}, \tilde{D}-R$

\begin{tabular}{|l|c|c|c|c|l|}
\hline & $\widetilde{\mathrm{D}}$ & $\widetilde{\mathrm{R}}$ & $\begin{array}{l}\mathrm{D} \\
+\widetilde{\mathrm{R}}\end{array}$ & $\widetilde{\mathrm{D}}-\widetilde{\mathrm{R}}$ & Result \\
\hline Security & 3.01 & 3.11 & 6.12 & -0.097 & influenced \\
\hline $\begin{array}{l}\text { Lack of access to confidential } \\
\text { organization information by the } \\
\text { contractor }\end{array}$ & 0.249 & 0.228 & 0.478 & 0.02109 & influencing \\
\hline Defect in dependency on companies & 0.239 & 0.255 & 0.494 & -0.0167 & influenced \\
\hline Defect in disclosing information of & 0.242 & 0.247 & 0.489 & -0.0044 & influenced \\
\hline Organization's capability & 3.48 & 3.36 & 6.83 & 0.12 & influencing \\
\hline
\end{tabular}




\begin{tabular}{|c|c|c|c|c|c|}
\hline $\begin{array}{l}\text { Improving the capability and releasing } \\
\text { the human resources within the } \\
\text { organization }\end{array}$ & 0.37 & 0.363 & 0.734 & 0.00691 & influencing \\
\hline Eliminating non-core activities & 0.359 & 0.334 & 0.694 & 0.02489 & influencing \\
\hline Obtaining competitive advantage & 0.373 & 0.429 & 0.802 & -0.0561 & influenced \\
\hline Access to specialty of contractors & 0.361 & 0.336 & 0.697 & 0.0243 & influencing \\
\hline Technological & 3.21 & 3.08 & 6.29 & 0.13 & influencing \\
\hline $\begin{array}{l}\text { Lack of human resource in applying } \\
\text { technology }\end{array}$ & 0.372 & 0.392 & 0.764 & -0.0202 & influenced \\
\hline Complexity of technology & 0.377 & 0.379 & 0.756 & -0.0021 & influenced \\
\hline Access to new technology & 0.397 & 0.387 & 0.784 & 0.00988 & influencing \\
\hline $\begin{array}{l}\text { Technological uncertainty (rapid } \\
\text { changes in technology) }\end{array}$ & 0.352 & 0.34 & 0.692 & 0.01242 & influencing \\
\hline Management & 3.44 & 3.6 & 7.03 & -0.162 & influenced \\
\hline Improving controlling and monitoring & 0.432 & 0.429 & 0.86 & 0.00312 & influencing \\
\hline Improving service quality & 0.408 & 0.422 & 0.83 & -0.0136 & influenced \\
\hline Motivation and morale of employees & 0.387 & 0.366 & 0.753 & 0.02159 & influencing \\
\hline Cost & 0.453 & 0.465 & 0.918 & -0.0111 & influenced \\
\hline Suppliers' market & 2.86 & 2.93 & 5.79 & -0.064 & influenced \\
\hline $\begin{array}{l}\text { Speed of provision of services by } \\
\text { contractors }\end{array}$ & 0.189 & 0.236 & 0.425 & -0.0475 & influenced \\
\hline Multiple and potential contractors & 0.196 & 0.217 & 0.413 & -0.0213 & influenced \\
\hline $\begin{array}{l}\text { Experience and background of } \\
\text { contractors }\end{array}$ & 0.213 & 0.145 & 0.358 & 0.06884 & influencing \\
\hline Activity characteristic & 2.92 & 2.85 & 5.77 & 0.073 & influencing \\
\hline Standardization of activities & 0.291 & 0.287 & 0.578 & 0.00414 & influencing \\
\hline Simplicity or complexity of activity & 0.292 & 0.306 & 0.598 & -0.0142 & influenced \\
\hline Tangibility of activity & 0.272 & 0.275 & 0.547 & -0.0033 & influenced \\
\hline $\begin{array}{l}\text { The level of dependency of an activity } \\
\text { to other activities }\end{array}$ & 0.285 & 0.272 & 0.557 & 0.01334 & influencing \\
\hline
\end{tabular}


Based on table 2-1, the factors that have positive $\widetilde{R}-\widetilde{D}$ show that these factors are influential and factors that have negative $\widetilde{\mathrm{R}}-\widetilde{\mathrm{D}}$ show that these factors are influenced by other factors. Therefore, among the primary factors "technological" is the most influencing factor and "management" is the mostly influenced factor. Generally, positive $\widetilde{\mathrm{R}}-\widetilde{\mathrm{D}}$ factors are considered cause factors and negative $\widetilde{\mathrm{R}}-\widetilde{\mathrm{D}}$ factors are considered as influenced factors.

\section{1-Weighting of factors by fuzzy ANP} method

The Network Analysis Process Method was presented in 1996 by Saaty for multiple criterion decision making. Its aim is to provide a model to break down complex multiple criterion decision-making problems into smaller components to make the final decision by giving reasonable value for simple components and then merging these values.

In this study, the fuzzy ANP was solved based on the general relations matrix showing to what extent these factors are influencing or being influenced. In this section, the general relations matrix was first normalized and the fuzzy weighted super matrix was calculated. After normalization, the weighted super matrix was converged to form a limited super matrix.

Finally, weights of factors and secondary factors were identified, as shown in Table 1-1

Table 3-1- Weight and priority of factors affecting outsourcing decision making

\begin{tabular}{|c|c|c|c|c|c|c|}
\hline \multicolumn{2}{|c|}{$\begin{array}{l}\text { Weight and relative priority } \\
\text { of primary factors }\end{array}$} & \multirow{2}{*}{$\begin{array}{l}\text { Code } \\
\text { C11 }\end{array}$} & \multicolumn{2}{|c|}{$\begin{array}{l}\text { Weight and relative } \\
\text { priority }\end{array}$} & \multicolumn{2}{|c|}{$\begin{array}{l}\text { Weight and final } \\
\text { priorit }\end{array}$} \\
\hline \multirow{3}{*}{$\begin{array}{l}\text { Security } \\
\text { C1 }\end{array}$} & \multirow{3}{*}{$\begin{array}{l}0.163 \\
(3)\end{array}$} & & 1 & 0.2789 & 0.0454 & 10 \\
\hline & & $\mathrm{C} 12$ & 3 & 0.4198 & 0.0683 & 1 \\
\hline & & C13 & 2 & 0.3013 & 0.0491 & 7 \\
\hline \multirow{4}{*}{$\begin{array}{l}\text { Organization's } \\
\text { capability } \\
\text { C2 }\end{array}$} & \multirow{4}{*}{$\begin{array}{l}0.182 \\
(2)\end{array}$} & C21 & 2 & 0.2265 & 0.0412 & 14 \\
\hline & & $\mathrm{C} 22$ & 1 & 0.2116 & 0.0385 & 17 \\
\hline & & $\mathrm{C} 23$ & 3 & 0.3213 & 0.0585 & 4 \\
\hline & & $\mathrm{C} 24$ & 4 & 0.2405 & 0.0438 & 11 \\
\hline
\end{tabular}




\begin{tabular}{|c|c|c|c|c|c|c|}
\hline \multirow{4}{*}{$\begin{array}{l}\text { Technological } \\
\text { C3 }\end{array}$} & \multirow{4}{*}{$\begin{array}{l}0.162 \\
(4)\end{array}$} & C31 & 4 & 0.2949 & 0.0479 & 9 \\
\hline & & C32 & 2 & 0.2569 & 0.0417 & 13 \\
\hline & & C33 & 3 & 0.2603 & 0.0422 & 12 \\
\hline & & C34 & 1 & 0.1879 & 0.0305 & 22 \\
\hline \multirow{4}{*}{$\begin{array}{l}\text { Management } \\
\text { C4 }\end{array}$} & \multirow{4}{*}{$\begin{array}{l}0.202 \\
(5)\end{array}$} & C41 & 3 & 0.2668 & 0.054 & 6 \\
\hline & & $\mathrm{C} 42$ & 2 & 0.2425 & 0.049 & 8 \\
\hline & & $\mathrm{C} 43$ & 1 & 0.1932 & 0.0391 & 16 \\
\hline & & C44 & 4 & 0.2975 & 0.0602 & 2 \\
\hline \multirow{3}{*}{$\begin{array}{l}\text { Suppliers' } \\
\text { market } \\
\text { C5 }\end{array}$} & \multirow{3}{*}{$\begin{array}{l}0.147 \\
(1)\end{array}$} & C51 & 3 & 0.4011 & 0.0588 & 3 \\
\hline & & C52 & 2 & 0.3877 & 0.0568 & 5 \\
\hline & & C53 & 1 & 0.2112 & 0.031 & 21 \\
\hline \multirow{4}{*}{$\begin{array}{l}\text { Activity } \\
\text { characteristic } \\
\text { C6 }\end{array}$} & \multirow{4}{*}{$\begin{array}{l}0.144 \\
(6)\end{array}$} & C61 & 3 & 0.2611 & 0.0376 & 18 \\
\hline & & C62 & 4 & 0.2832 & 0.0408 & 15 \\
\hline & & C63 & 2 & 0.2329 & 0.0336 & 19 \\
\hline & & C64 & 1 & 0.2228 & 0.0321 & 20 \\
\hline
\end{tabular}

As Table 3-1 shows, the highest weight belonged to the factor of "defect in dependency on companies providing service" which is a secondary factor of "security", so it was ranked first. The second priority belonged to "cost" factor, the third priority belonged to speed of providing the services by contractors, the forth priority belonged to "competitive advantage", the fifth priority belonged to "presence of multiple and potential contractors", and sixth priority belonged to "improvement of control and monitoring" among the 22 factors. They approximately accounted for $35.65 \%$ of the total weight of the factors, indicating the high importance of these secondary factors.

5.2-Fuzzy MOORA (multi-objective optimization on the basis of ratio analysis) method

The MOORA method was proposed by Brauers and Zavadskas (2006). Then, fuzzy MOORA was developed. This technique is a multiobjective optimization method that can be used to solve a variety of complex 
problems. It means multi-objective optimization on the basis of ratio analysis (Akkaya et al., 2015).

As stated above, based on interviews performed with banking experts, the following three activities were selected to prioritize activities in the banking system:

1-Human resources sector activities (A1)

2- Logistics and support sector activities (A2)

3- Legal and claims receivable sector activities (A3)

The prioritization of these activities was performed using the fuzzy MOORA technique as follows. First, a comparisons matrix was used to determine the importance of each factor relative to the options. It was completed by 7 experts.

Considering the decision makers' views by geometric mean method, the component of fuzzy
206

numbers was calculated for each option (outsourcing activities) and the fuzzy decision matrix was formed.

Then, the fuzzy decision matrix was normalized and the aggregated normalized fuzzy decision matrix was obtained.

Then, weighted normalized fuzzy decision matrix was calculated by multiplying the normalized fuzzy decision matrix on the fuzzy weight of the sub-factors.

To rank with the fuzzy MOORA method, it is necessary to obtain the value of each option in the cost and profit factors. At this stage, the sum of the value of each option was calculated on the cost factors and profit factors. Then, the general performance index $(\mathrm{Si})$ for each of the options was obtained by the vertex method $S_{i}\left(s_{i}^{+}, s_{i}^{-}\right)=\sqrt{\frac{1}{3}\left[\left(s_{i}^{+l}-s_{i}^{-l}\right)^{2}+\left(s_{i}^{+m}-s_{i}^{-m}\right)^{2}+\left(s_{i}^{+n}-s_{i}^{-n}\right)^{2}\right]}$ , as shown in Table 1-4:

Table 4-1: Ranking activities for outsourcing by using fuzzy MOORA method

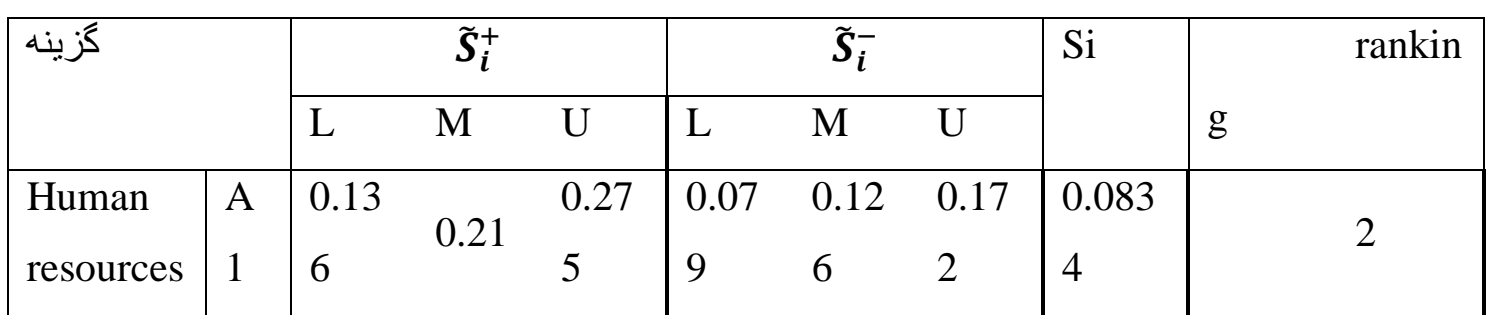




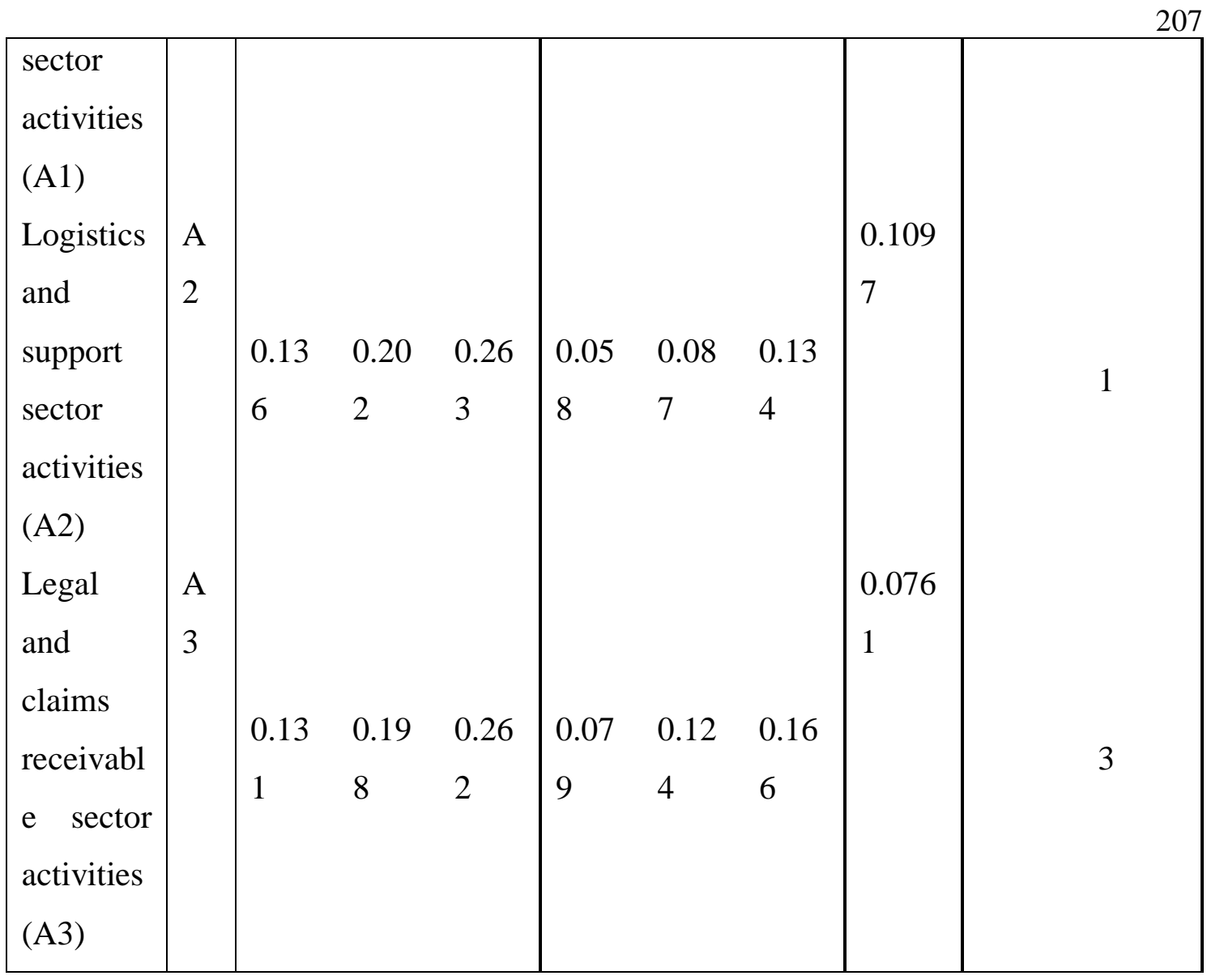

The value gained of the options is sorted and ranked in ascending order. Accordingly, the option with the highest $\mathrm{Si}$ value is selected as the superior option. Therefore, "logistics and support sector activities" option was selected was ranked first for outsourcing using fuzzy MOORA as it obtained the highest weight. The "human resources sector" activity was also ranked second.

\section{3-Gray MOORA}

To form the gray decision matrix, the linguistic variables shown in Table 5-1 are transformed to gray numbers and the gray evaluation decision matrix is formed.

Table 5-1: Linguistic variables for ranking options

\begin{tabular}{|l|l|}
\hline Linguistic variables & $\begin{array}{l}\text { Corresponding gray } \\
\text { numbers }\end{array}$ \\
\hline Very poor (VP) & $(1,2)$ \\
\hline
\end{tabular}




\begin{tabular}{|l|l|}
\hline Poor $(\mathrm{P})$ & $(3,4)$ \\
\hline Moderate $(\mathrm{P})$ & $(5,6)$ \\
\hline Good $(\mathrm{G})$ & $(7,8)$ \\
\hline Very good $(\mathrm{VG})$ & $(9,10)$ \\
\hline
\end{tabular}

Then, the decision-making matrix of options ranking was calculated based on the views of decision makers and after the geometric aggregation of the views of experts.

Then, gray decision matrix was normalized. Then, the weighted normalized gray decision matrix was calculated by multiplying the normalized gray decision matrix in fuzzy weight of sub-factors.
The value of each option in the cost criteria needs to be calculated for ranking. At this stage, the sum of the value of each of the options was calculated in the cost criteria. Then, the general performance index $(\mathrm{Si})$ for each of the options was obtained by using the distance method between the two gray numbers as shown as using the formula of

$$
d(\bar{A}, \bar{B})=\frac{a_{1}+a_{2}}{2}-\frac{b_{1}+b_{2}}{2}=\frac{1}{2}\left[\left(a_{1}-b_{1}\right)+\left(a_{2}-b_{2}\right)\right] .
$$

Table 6- 1: ranking bank outsourcing activities by Gray MOORA Method

\begin{tabular}{|c|c|c|c|c|c|c|c|}
\hline & \multicolumn{2}{|c|}{$\tilde{\boldsymbol{S}}_{i}^{+}$} & \multicolumn{2}{|c|}{$\tilde{\boldsymbol{S}}_{\boldsymbol{i}}^{-}$} & \multirow[t]{2}{*}{$\mathrm{Si}$} & \multirow[t]{2}{*}{ rank } \\
\hline & & $\mathrm{L}$ & M & $\mathrm{L}$ & $\mathrm{M}$ & & \\
\hline $\begin{array}{l}\text { Human resources sector activities } \\
\text { (A1) }\end{array}$ & A1 & 0.237 & 0.277 & 0.149 & 0.182 & 0.008 & 2 \\
\hline $\begin{array}{l}\text { Logistics and support sector } \\
\text { activities (A2) }\end{array}$ & A2 & 0.227 & 0.269 & 0.103 & 0.139 & 0.016 & 1 \\
\hline $\begin{array}{l}\text { Legal and claims receivable sector } \\
\text { activities (A3) }\end{array}$ & A3 & 0.222 & 0.263 & 0.146 & 0.179 & 0.007 & 3 \\
\hline
\end{tabular}

Based on the results in Table 6-

1, the "Logistics and support sector activities" option obtained the highest weight and it was ranked first. 
Table 7-1 shows the final ranking between the two gray and fuzzy MOORA methods:

Table 7- 1: Final ranking using two fuzzy and gray MOORA methods

\begin{tabular}{|l|l|l|l|}
\hline G-MOORA & F-MOORA & \multicolumn{2}{|l|}{} \\
\hline 2 & 2 & Human resources sector activities (A1) & A1 \\
\hline 1 & 1 & Logistics and support sector activities (A2) & A2 \\
\hline 3 & 3 & Legal and claims receivable sector & A3 \\
\hline
\end{tabular}

As shown in Table 7-1, there is no difference between the fuzzy 6-Conclusion and final model MOORA and gray MOORA ranking methods.

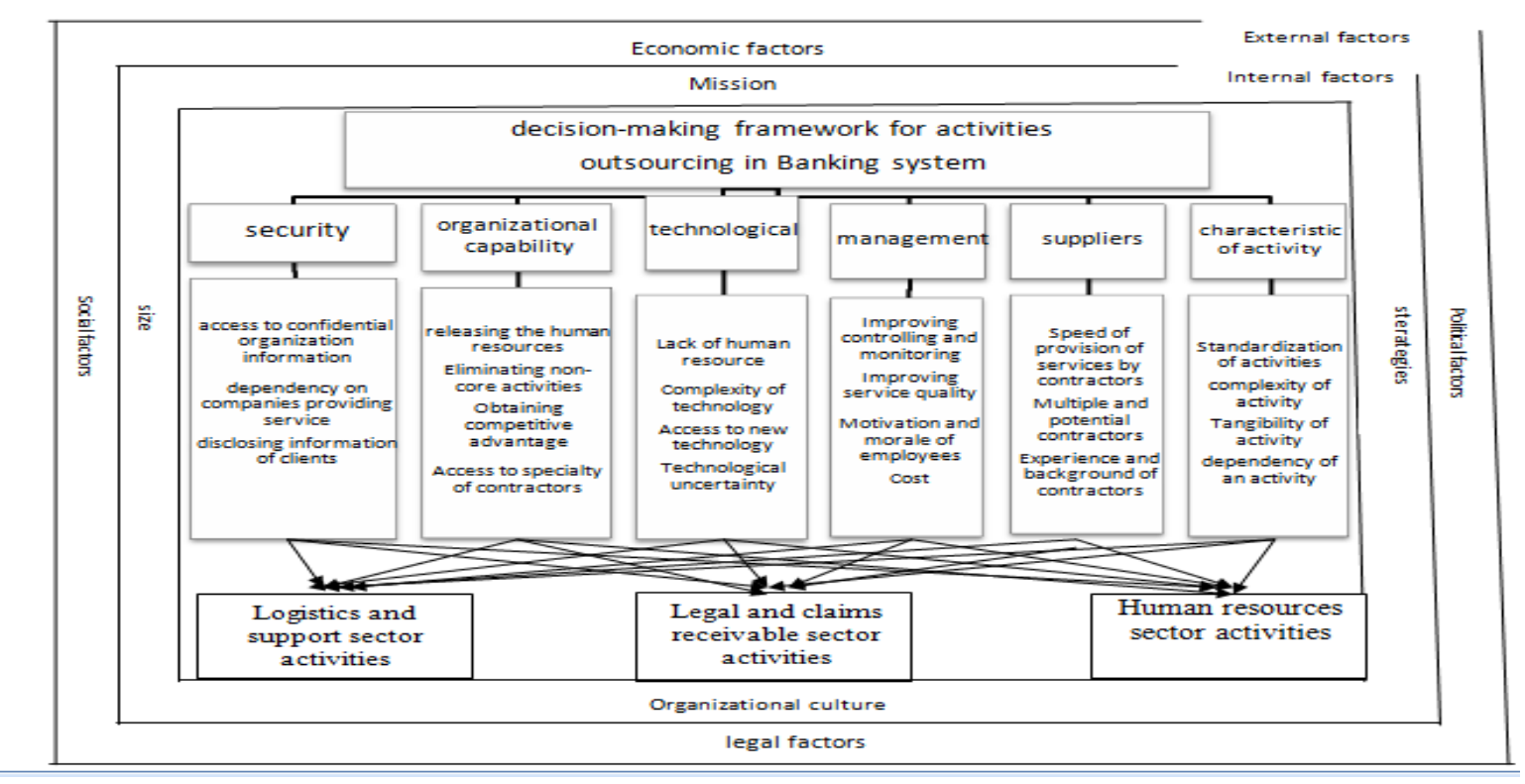

The aim of this study is to identify the criteria and standards for decision making regarding outsourcing of activities in Iran's public banks.
The results of literature review and Delphi three rounds showed that 6 main factors influence the outsourcing decisions in the Iran's public banks. Among the factors, goods and service 
suppliers, organization's capability and security criteria had the highest priority. Among the secondary factors, the highest weight belonged to the factor of "defect in dependency on companies providing service" which is a "security" factor.

The literature on outsourcing activities has discussed numerous risks in this regard. An organization can rely on a few service providers and accordingly it is influenced by them .Obviously, banks have lower tendency to outsource activities or processes related to security issues.

As expected, the cost factor is a very important criterion in the outsourcing of activities in the Iran's public banks. In general, an organization can perform its services at a lower cost than its competitors with outsourcing its activities can. Reduced manpower and operational costs are outcomes of the outsourcing (Dastyari et al., 2014).

"Speed of providing service by contractors" is the third priority among the criteria of making decision on outsourcing the activities in public banks. This secondary factor indicates that managers expect that providers to provide the required services of the bank in the shortest possible time, as lack of it will reduce the competitive power of the bank. It is highlighted when there is a competition among the banks (Nahavandi et al., 2010).

$$
\text { "Gaining competitive }
$$
advantage" is the fourth priority among the criteria of making decision on outsourcing the activities in public banks. Outsourcing enables banks use their resources more effectively to create value and gain competitive advantage by focusing on their core activities. Hence, in outsourcing decisions, managers did not show tendency to outsource activities that create competitive advantage for the organization (Olfat and Barati, 2010).

"Existence of numerous and potential contractors" is the fifth priority. In order to outsource an activity, a bank requires potential suppliers for that activity. If there is only one supplier, the company needs to show lower tendency to outsource the activity, because it is associated with a risk of complete dependency on the supplier, which this secondary factor is highly associated with secondary factor of "defect in dependency to companies providing services, as stated before. Thus, the greater the number of potential suppliers, 
the tendency for outsourcing the activity will be higher (Masrour et al., 2018).

Finally, "improving the process of controlling and monitoring" is the sixth priority among the criteria of making decision on outsourcing the activities in public banks. Outsourcing not only involves assigning the activity by the outsourced organization but also involves assigning the right of decisionmaking to external supplier. By assigning the right of decision-making, external supplier will make the decision and it will be responsible for consequences of its decisions to the outsourcer organization. Hence, it allows the outsourcer organization to focus more on its core competences. It will also help the bank improve the process of controlling and monitoring other activities.

Based on the obtained indicators, the highest priority belonged to logistics and support sector activities, banks should give priority for this type of activities to cooperate with the private sector. Human resources activities and legal and claims receivable activities were also ranked second and third, respectively, in outsourcing the activity to private sector.
This research was conducted to develop a model to deal with the complexities of decision making in the real world. In general, the results of this study emphasize that the onedimensional outlook of the outsourcing decision-makers will not lead to the desired results. As the Iran's economy is a bank-centered economy and banking system affects the economy and lives of citizens, if the focus of decision-makers is merely on cost factors or on a limited set of factors, we cannot be optimistic for future of such decisions.

\section{Refrecnces}

Ackermann, M. (2003). Banks' major users, providers in 1Q of outsourced services. American Banker, 75, 6.

Adeleye, B. C., Annansingh, F., \& Nunes, M. B. (2004). Risk management practices in IS outsourcing: an investigation into commercial banks in Nigeria. International Journal of Information Management, 24(2), 167180.
Ai, S., Du, R., Straub, D. W., Maruping, L. M., \& Miao, Y. (2019). Measuring creolization in IT outsourcing: 
Instrument development and validation. International Journal of Property Management, 29, 195-212.

Information Management, 47, 16-30.

Akbari,H,Nikzad.S,(2011), The most widely used management tools in Iranian organizations. Tadbir journal.217,24-28

Akkaya , G., Turanogù lu , B., Oztasü , S. (2015). An Integrated Fuzzy AHP And Fuzzy MOORA Approach to The Problem of Industrial Engineering Sector Choosing, Expert Systems With Applications (2015), doi: 10.1016/j.eswa.2015.07.061

Alvani , M , Ashrafzadeh , Farzad, (2012) , Outsourcing Management, a path to development Tehran,Mobtakeran.

Amoako-Gyampah, K., \& Salam, A. F. (2004). An extension of the technology acceptance model in an ERP implementation

environment. Information $\&$ management, 41(6), 731-745.

Assaf, S., (2011). Factors affecting oytsourcing decisions of maintenance
Axelrod C.W, 2009 ,Combined impact of outsourcing and hard times on BPO risk and security; DOI: 10.4018/978-160960-123-2.ch002

Bagheri,M,Ebrahimi,A,Kiani,M,(2015), Designing Model of Factors Affecting Decision Making for Outsourcing of Activities, Journal of Management Improvement, Issue 9,No3,137-166

Blumenberg, S., Wagner, H. T., \& Beimborn, D. (2009). Knowledge transfer processes in IT outsourcing relationships and their impact on shared knowledge and outsourcing performance. International Journal of Information Management, 29(5), 342352.

Brauers,Willem, Zavadskas,Edmundas (2006).The MOOR method and its application in transition economy,control and cybernetics, $\mathrm{Vol}$ 35,No 2,445-471

Cheng, Ching-Hsue \& Lin, Yin . (2002), Evaluating the best mail battle 
tank using fuzzy decision theory with linguistic criteria evaluation, European Journal of Operational Research, vol.142, p.147

Choudhry, A. Z. (2014). Application Outsourcing Governance Model: Critical components of a Successful Application Outsourcing Governance Framework.

Click, R.L. and Duening, T.N. (2004), Business Process Outsourcing: The Competitive Advantage.

Dastyari,A,Mohammadi,M,Bardestani, $\mathrm{H},(2014)$, Outsourcing in Human Resource Management, First International Conference on Economics, Management, Accounting and Social Sciences.

Di Gregorio, D., Musteen, M., \& Thomas, D. E. (2009). Offshore outsourcing as a source of international competitiveness for SMEs. Journal of International Business Studies, 40(6), 969-988.

Farzad,F,Maddah,M,Hamidi,A,(2012),E xplanation and Evaluation of Information Technology Outsourcing
Strategy, Strategic Management

Studies,No 11,87-104

Fiorentino, Elisabetta (2009). “The effects of privatization and consolidation on bank productivity: comparative evidence from Italy and Germany". Series 2: Banking and Financial Studies, (3).

Frost \& Sullivan, (2004)Making IT Outsourcing Work: Journal of Strategic Information Systems, Vol.14, PP.357387

Gottschalk, P, 2006, managing successful it outsourcing relationship .

Grandon, E. E., \& Pearson, J. M. (2004). Electronic commerce adoption: an empirical study of small and medium US businesses. Information $\&$ management, 42(1), 197-216.

Gray, J. V. (2006). Essays on manufacturing outsourcing. The University of North Carolina at Chapel Hill.

Gulzhanat Tayauova (2012) Advantages and disadvantages of outsourcing: 
analysis ofoutsourcing practices of Kazakhstan banks Procedia - Social and Behavioral Sciences 41, 188 - 195

Hanafizadeh, P., \& Zare Ravasan, A. (2017). An investigation into the factors influencing the outsourcing decision of e-banking services: a multi-perspective framework. Journal of Global Operations and Strategic Sourcing, 10(1), 67-89.

Henrik Höglund,(2016), Financial reporting quality and outsourcing of accounting tasks: evidencefrom small private firms. Advances in Accounting, incorporating Advances in International Accounting 35 125-134

Isa Zadeh ,S, Saheri,Z,(2012),Investigating the Effect of Macroeconomic Stability on Efficiency of Banking System, Economics, Monetary and Financial Bimonthly Journal,Issue 19,No3,53-87

Keuschnigg Ch, 2009,"Outsourcing, unemployment and welfare policy", Journal of International Economics $78,168-176$ DOI:
Kuhani,P,Nooronesa,R,Azimi,N(2013)

Analysis of Factors Affecting Outsourcing of Organizational Activities, Supply Chain Management Quarterly,Issue 16,No43,40-46

Law, F. (2018). Breaking the outsourcing path: Backsourcing process and outsourcing lock-in. European Management Journal, 36(3), 341-352.

Lee, S. D., \& Lan, S. C. (2013). Production lot sizing with a secondary outsourcing facility. International Journal of Production Economics, 141(1), 414-424.

Lewis, David, 2001, NGOs and Management" Searching for New Modles or Reinventing The Wheel", Center for Civil Socity in London of Economics.

Masrur

„H,Tofigh,A,Ghazizadeh,Z(2018), Introducing Risk Identification and Evaluation Model for Outsourcing R\&D Projects, Management Improvement Scientific Journal.Issue 8,No4,63-82

10.1016/j.jinteco.2009.02.001 
McIvor, Ronan, (2008), What is the right outsourcing strategy for your process? European Management Journal, volume $26,24-34$

Nahavandi,N,Yusefian,M,Bayat,A(2010 ).Determining Information Technology Outsourcing Strategy in Iranian Banks, Journal of Modern Economics and Business.No13,89-110

Nikolaos K. Liapopoulosa, Socrates J. Moschurisb, 2013, An Empirical Investigation of Outsourcing Decisions in Enterprises Operating in Greece, SPOUDAI Journal, Vol. 63 (2013), Issue $1-2$, pp. $31-46$

Olfat,L, Barati,M,(2010),A Model for Outsourcing Decision Making in Banking Industry and Mining, Business Strategies,Issue 19,No2,25-41

Parvyzyan, K., Naieri, F.2006. Strategic utsourcing and investment risk in the value chain, the second national conference on sustainable investment risk National Conference Center,Tehran University.,14
Perunović, Z., \& Pedersen, J. L. (2007).

Outsourcing process and theories. In Proceedings of the POMS 18th Annual Conference, May 4-7, Dallas, Texas, 007 (Vol. 3).

Rajabzadeh,A,Azar,A,Hoseini,A,(2010)

,Developing and Analyzing the Components of Outsourcing in the Public Sector, Business Strategies, Issue 19,No2,99-119

Rezaei,M,Shiraghaee,M, Mozdgir,A, (2015),Investigating the Effects of Organizational Culture on Outsourcing, Second Internal Capacity Building Conference with Contractor System Development Approach.

Schniederjans,

A. (Ed.). (2006). Outsourcing management information systems. IGI Global.

Sean M.H., W.C. Benton Jr.; 2009,"Unlocking the business outsourcing process model"; Journal of operations Management 27.344-361

Sia, S. K., Koh, C., \& Tan, C. X. (2008). Strategic maneuvers for outsourcing flexibility: an empirical 
assessment. Decision Sciences, 39(3), 407-443.

Tabatabaei,M,

Mohammadi,P(2015),Investigating the Use of Outsourcing in Challenging Islamic Banking, Islamic Economics \& Banking Extension,No17,59-76

Tas, J., \& Sunder, S. (2004). Financial services business process outsourcing. Communications of the ACM, 47(5), 50-52.

Tayauova, G. (2012). Advantages and disadvantages of outsourcing: analysis of outsourcing practices of Kazakhstan banks. Procedia-Social and Behavioral Sciences, 41, 188-195.

Tayles. Mike ,2001,"Moving from Make/Buy to Strategic Sourcing: The Outsource Decision Process", Long Range Planning 34,605-622

Teo, T. S., Lin, S., \& Lai, K. H. (2009). Adopters and non-adopters of eprocurement in Singapore: An empirical study. Omega, 37(5), 972-987.
Tjader, Y., May, J. H., Shang, J., Vargas, L. G., \& Gao, N. (2014). Firm-level outsourcing decision making: A balanced scorecard-based analytic network process model. International Journal of Production Economics, 147, 614-623.

Zailani,Suhaiza,Iranmanesh,Mohamma

d, Razmi,Khairful (2015),Influential factors and performance of logistics outsourcing practices: an evidence of Malaysian companies-Springer-Verlag Berlin Heidelberg 2015-published online.DOI 10.1007/S11846-015-0180$\mathrm{X}$

Zhang, Z., \& Gibson, B. (2016). Determinants of outsourcing in US Municipalities: Evidence from a municipal spatial network analysis. Applied Spatial Analysis and Policy, 10(2), 253-269

Zhu, K., \& Kraemer, K. L. (2005). Postadoption variations in usage and value of e-business by organizations: crosscountry evidence from the retail industry. Information systems research, 16(1), 61-84. 
Periódico do Núcleo de Estudos e Pesquisas sobre Gênero e Direito

Centro de Ciências Jurídicas - Universidade Federal da Paraíba V. 9 - $\mathrm{N}^{\circ} 02$ - Ano 2020

ISSN | 2179-7137 | http://periodicos.ufpb.br/ojs2/index.php/ged/index

Zhu, W., Ng, S. C., Wang, Z., \& Zhao,

X. (2017). The role of outsourcing

management process in improving the

effectiveness of logistics

outsourcing. International Journal of

Production Economics, 188, 29-40 